\title{
Role of recruitment in causing differences between intertidal assemblages on seawalls and rocky shores
}

\author{
Fabio Bulleri* \\ Centre for Research on Ecological Impacts of Coastal Cities, Marine Laboratories A11, University of Sydney, \\ New South Wales 2006, Australia \\ Present address: Dipartimento di Scienze dell'Uomo e dell'Ambiente, Università di Pisa, Via A. Volta 6, 56126 Pisa, Italy
}

\begin{abstract}
Following progressive urbanisation of coastal areas, artificial structures are becoming common features of landscapes in shallow waters. Despite this, few studies have focused on the ecological role of these structures or have attempted to assess the extent to which they can act as surrogates for natural habitats. This study investigated whether colonisation of space can determine the occurrence of different intertidal assemblages on rocky shores and sandstone seawalls in Sydney Harbour (New South Wales, Australia). Areas were cleared on rocky shores and seawalls at 3 different locations to test hypotheses from 2 alternative models: (1) patterns of distribution and abundance of organisms on the 2 types of structure are the direct result of different patterns of recruitment and (2) early stages of development of assemblages are the same on the 2 types of structure, but later processes (post-recruitment) differ between structures, producing different older assemblages. Furthermore, the model that assemblages developing in clearings on each structure would converge toward mature assemblages found on the same type of structure was tested. Assemblages in clearings differed between seawalls and rocky shores from the early stages of succession and differences persisted through time. Although there was variability among locations, these assemblages tended to converge toward mature assemblages on the same type of structure. These results support the model that intrinsic differences (e.g. topography, weathering, shape and extent of surfaces) between seawalls and rocky shores could affect the recruitment of algae and invertebrates, leading to the establishment of distinct assemblages. This knowledge could improve our ability to design artificial structures that more closely mimic natural habitats, potentially mitigating some effects of loss and fragmentation of coastal habitats in urban areas.
\end{abstract}

KEY WORDS: Urbanisation · Coastal management · Artificial structures · Intertidal · Recruitment • Succession

\section{INTRODUCTION}

Urbanisation is transforming landscapes throughout the world, affecting the structure and functioning of natural systems at a variety of scales, from local to regional (McDonnell \& Pickett 1990, Pickett et al. 2001). Following this trend, a plethora of studies has focused on climatic conditions (McDonnell et al. 1993, Zipperer et al. 1997), soils (Hollis 1991), flora (Hobbs
1988) and fauna (Gilbert 1989) in human conglomerates. Although the population living on the coast will double in the next 30 yr (Hammond 1992, Gray 1997), the effects of urbanisation on marine environments have received little attention in comparison to terrestrial and riparian counterparts (reviewed in Pickett et al. 2001 and Paul \& Meyer 2001, respectively).

The effects of urbanisation in estuarine and coastal areas vary from an increase in suspended and organic 
matter, and chemical pollutants in the water-column (Gabric \& Bell 1993, Crawford et al. 1995), to the introduction of a variety of artificial structures in intertidal and shallow subtidal habitats. These range from roads and buildings to breakwaters, pontoons, pier-pilings and seawalls (Glasby \& Connell 1998, Connell \& Glasby 1999, Glasby 1999, Bulleri et al. 2000, Davis et al. 2002, Bacchiocchi \& Airoldi 2003, Chapman 2003, Chapman \& Bulleri 2003, Bulleri \& Chapman 2004). Artificial habitats can represent the most common intertidal and shallow subtidal habitats in urban coastal areas and it is, therefore, arguable that understanding their ecology is as important as understanding the ecology of natural coastal habitats (Holloway \& Connell 2002). Furthermore, in order to preserve and manage marine natural habitats in coastal areas, it is of fundamental importance to assess the extent to which artificial structures resemble natural habitats. The identification of the processes which cause different assemblages of organisms to develop on natural or artificial structures is crucial to improving the design of future artificial structures, so that they will more closely mimic natural habitats being replaced.

Chapman \& Bulleri (2003) and Bulleri et al. (in press) have shown that, in Sydney Harbour, mid-shore assemblages on seawalls are distinct from those found on adjacent vertical rocky shores, although they are made of the same material (sandstone). It is, therefore, of value to identify the mechanisms that could be responsible for these differences.

Variability in post-settlement mortality, due to differential competition, predation or environmental harshness, has long been considered the main force structuring intertidal assemblages of sessile organisms on rocky shores (Dayton 1971, Lubchenco \& Menge 1978). In recent decades, alternative models, emphasising the importance of spatial and temporal variability in the supply of larvae and propagules from plankton, settlement and early post-settlement mortality, have been incorporated into existing theory to explain patterns of distribution and abundance of marine benthic organisms (Denley \& Underwood 1979, Caffey 1985, Connell 1985, Underwood \& Fairweather 1989).

Intrinsic differences in physical features between natural and artificial structures, at a variety of scales, could underlie the establishment of different intertidal assemblages (Wolanski \& Hamner 1988, Anderson \& Underwood 1994, Bourget et al. 1994, Abelson \& Denny 1997). For example, in Sydney Harbour, seawalls extend further along the shore (uninterrupted) and rise higher than vertical surfaces on rocky shores. Due to their limited vertical extension, waves pass over the tops of vertical ledges on rocky shores (F. Bulleri pers. obs.), possibly affecting turbulence and flow of the water in the vicinity of the substratum (Denny
1988), particularly at mid to high tidal levels. Alternatively, seawalls may experience more intense hydrodynamic forces, from breaking waves throughout the tide. At smaller spatial scales, seawalls are characterised by crevices among blocks (Bulleri et al. in press), which only occasionally occur on vertical surfaces on rocky shores. Hence, this study was aimed at determining whether different recruitment of organisms between rocky shores and seawalls, in response to intrinsic physical differences between these structures, could account for patterns in mature assemblages.

Two general models were proposed. In the first, patterns of distribution and abundance of organisms on the 2 types of structure are considered to be the direct result of different patterns of recruitment on rocky shores and seawalls. Whatever the effects on later colonisers (sensu Connell \& Slatyer 1977), early colonisers would lead to the development of distinct adult assemblages on these structures. According to this model, it was predicted that assemblages establishing in new clearings created on rocky shores and seawalls would differ between these 2 habitats from the start of the colonisation of available space and that differences would persist through time. The deterministic concept of succession (Clements 1936) has been challenged by some authors (Connell \& Slatyer 1977, Sousa 1984) and there is considerable evidence indicating that succession can be variable, complex and context-dependent (Connell et al. 1987, Chapman \& Underwood 1998, Benedetti-Cecchi 2000). An alternative model proposes that early stages of development of assemblages are the same on the 2 types of structure, but later processes differ between structures, producing different older assemblages. Following this model, it was predicted that assemblages developing in clearings on rocky shores and seawalls would be similar during the early stages of colonisation, but would follow different trajectories through time, becoming more different.

Finally, the model that mature assemblages on each type of structure have arisen from patterns of colonisation similar to those described in this experiment was tested. It was, therefore, predicted that assemblages developing in clearings on each structure would converge toward mature assemblages occurring on the same type of structure.

\section{MATERIALS AND METHODS}

Study site. This study was done in Sydney Harbour from August 2000 to September 2002. Three locations, 1000 s of metres apart, with a seawall and a vertical rocky shore, adjacent, or separated by a distance of a few 
metres, were chosen haphazardly (Fig. 1). At each location, both the rocky shore and the seawall were made of sandstone and appeared to have a similar exposure to wave-action. One location, Old Quarantine Station (hereafter referred to as Location 1), was in North Harbour, while the other 2, Hermit Point and Clark Island (hereafter referred to as Locations 2 and 3, respectively), were in Middle Harbour. Intertidal habitats on natural and artificial substrata at the study sites support a diverse assemblage of organisms, including algae and invertebrates (Chapman \& Bulleri 2003, Bulleri et al. in press).

Experimental design. This study was performed about 0.9 to $0.7 \mathrm{~m}$ above the Mean Low Water, because of the previously documented differences between assemblages on natural and artificial structures at this height on these shores (Chapman \& Bulleri 2003, Bulleri et al. in press).

At each location, 4 patches, each about $8 \mathrm{~m}$ long, were selected at random on each structure (seawall and rocky shore). Twelve $13 \times 13 \mathrm{~cm}$ clearings were produced, 10s of centimetres apart, in each of 2 randomly chosen patches on seawalls and rocky shores. Mature assemblages in each of the other 2 patches were left untouched. Seawalls were made of sandstone

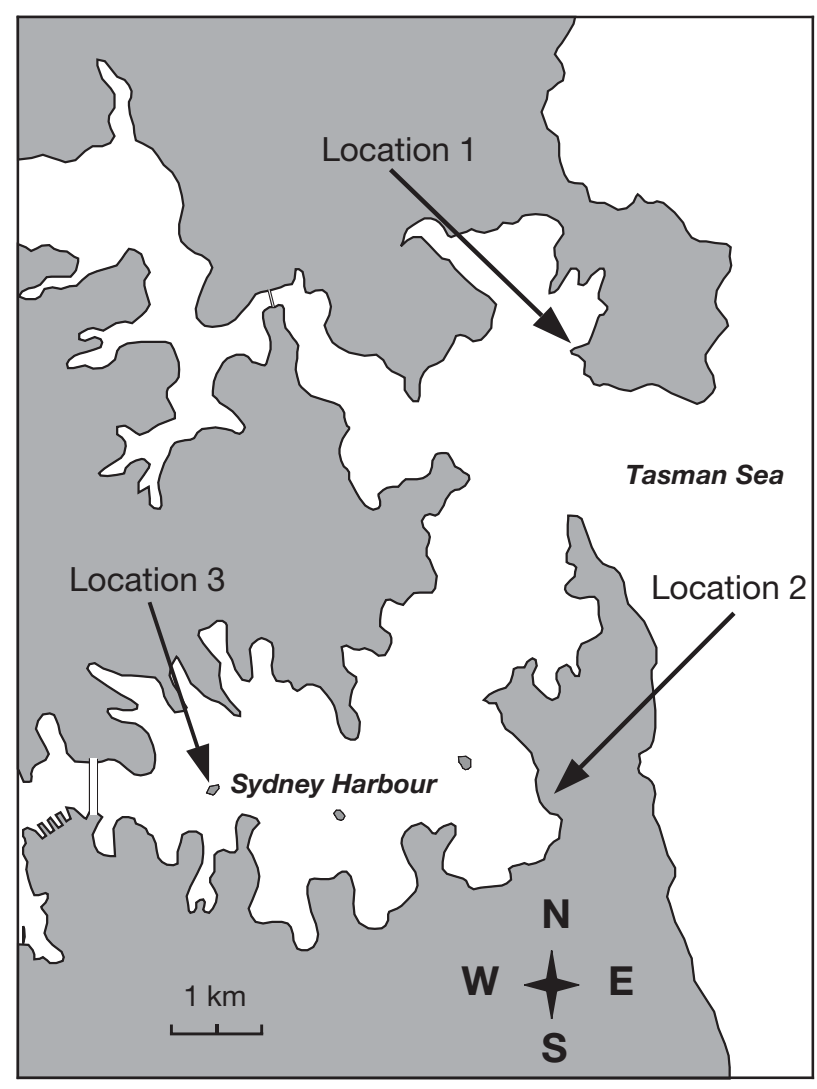

Fig. 1. Locations of study within Sydney Harbour (New South Wales, Australia) blocks, with sizes varying from $120 \times 40$ to $70 \times 30 \mathrm{~cm}$. Clearings were made on the surface of the blocks, at least 15 to $20 \mathrm{~cm}$ from crevices between adjoining blocks. All organisms were removed by using a hammer and chisel, whilst trying not to alter the features of the substratum by adding cracks or crevices. After most of the visible organisms were removed, the surface was burnt with a propane gas torch, to eliminate encrusting and endolithic algae. The size of clearings simulated the sizes of patches often produced by natural disturbance on rocky shores in the region (Chapman \& Underwood 1998, F. Bulleri unpubl. data). At Location 1, because of the presence of a gently sloping section, it was not possible to find a continuous stretch of vertical surface on the rocky shore. In this case, some replicates were placed on the nearby stretch of vertical shore. These units were, however, no more than 1 to $2 \mathrm{~m}$ apart from the main group.

Three different subsets of 4 randomly-chosen quadrats, either clearings or mature assemblages, were sampled in each patch at each of 3 times: 3, 6 and about 24 mo after the initiation of the experiment (hereafter referred to as Times 1, 2 and 3, respectively).

Each quadrat was sampled only once, providing data which were independent through time (Underwood 1997). A margin, $3 \mathrm{~cm}$ wide, was left to avoid any edgeeffects and the $10 \times 10 \mathrm{~cm}$ central area of each clearing was sampled. Given the relatively short duration of the experiment, a $3 \mathrm{~cm}$ buffer zone prevented resident species encroaching from the margin of the cleared patches (F. Bulleri pers. obs.) and so the developing assemblages can be reliably considered to be the result of the supply of larvae and propagules directly from the plankton. Quadrats were sampled by means of a frame supporting a grid of 25 intersecting points. The percentage cover was estimated for primary and secondary substrata as the total occurrence of a given species underneath each point, multiplied by 4 . Species or taxa, present in the quadrat, but not under any intersection point were given a score of $0.5 \%$.

As this study aimed at investigating whether intrinsic differences in physical structure of rocky shores and seawalls were responsible for different patterns of colonisation of space, the most common herbivores were excluded from experimental areas to limit the impact of grazing on developing assemblages (Sousa 1979, Anderson \& Underwood 1997, Benedetti-Cecchi 2000). The effects of grazers on the colonisation of space on rocky shores and seawalls were investigated at Location 3 (F. Bulleri unpubl. data). On each type of structure, 12 clearings were produced in each of 2 extra patches (randomly identified at the beginning of the study), where herbivores were left untouched. The effects of grazers on development of assemblages in clearings were assessed by means of NP-MANOVAs 
(Anderson 2001, renamed PERMANOVA), including the factors Herbivore (present versus absent) and Structure (rocky shore versus seawall). At all sampling times $(3,6$ and 24 mo from the start of the experiment), there were significant main effects of Structure and Herbivore $(p<0.05)$, but not significant effects of their interaction $(p>0.10)$. Even if the study was limited to 1 location, these results suggest that the effects of physical attributes of the natural and artificial structures investigated on the development of assemblages did not vary according to the presence or absence of grazers.

Nevertheless, the gastropods Cellana tramoserica, Montfortula rugosa, Patelloida alticostata and Patelloida latistrigata, the chiton Chiton pelliserpentis and the starfish Patiriella exigua were removed from the experimental patches by hand, using a screwdriver. Their removal was limited to a narrow vertical band, extending about $5 \mathrm{~cm}$ above and below the cleared quadrats, so as not to change the surrounding assemblages. Fortnightly removals were necessary to maintain the clearings free of herbivores during the first year. Afterwards, due to a general decrease in the abundance of herbivores, monthly removals were sufficient to maintain the experimental conditions. During visits to the field, grazers were rarely found inside or nearby cleared areas and, on those occasions, only juvenile individuals, mostly recruits of $P$. latistrigata (shell-length $<0.5 \mathrm{~cm}$ ), were observed (F. Bulleri unpubl. data).

Statistical analyses. Assemblages developing in the clearings on rocky shores and seawalls were compared using nMDS (Clarke 1993) and NP-MANOVAs (Anderson 2001) on Bray-Curtis similarity coefficients (Bray \& Curtis 1957), calculated using untransformed data. A first set of analyses, including the factors Structure (rocky shore versus seawall; fixed) and Patch (random and nested within Structure), were performed to check whether there was significant variability among patches. Generally, that was not the case ( $p>0.05)$ and therefore, replicate quadrats from each patch were pooled on each structure $(n=8)$, to allow 2 -factor NPMANOVAs including the factors Time (fixed) and Structure (fixed and orthogonal), as required to formally test the predictions. The factor Time was considered a fixed factor, each time representing a different period since colonisation of clearings began. Taxa contributing at least $10 \%$ of dissimilarity between structures for any location or time were considered to be important differentiators.

To test the hypothesis that assemblages in clearings on each structure would become more similar to mature assemblages on the same structure than to mature assemblages on the other structure, the dissimilarity between clearings and mature assemblages on the same structure was compared to the dissimilarity be- tween clearings on one structure and mature assemblages on the other. For each combination of time, location and structure, 4 clearings were separately paired with 4 quadrats within mature assemblages on the same structure (hereafter referred to as within a structure), whilst the remaining 4 clearings were paired with 4 quadrats within mature assemblages on the other kind of structure (hereafter referred to as between structures). Pairing of clearings and quadrats within mature assemblage was random and, since each sample (either clearing or mature assemblage) was used only once, data were not dependent through time and could be analysed by means of a 4 -factor mixed model ANOVA, including Time (fixed), Location (random and orthogonal), Structure (fixed and orthogonal) and Within versus Between (fixed and orthogonal).

Hypotheses about abundances of those species which distinguished between assemblages in clearings on seawalls and rocky shores and of those which were shown to be important components of mature assemblages on these structures (Bulleri et al. in press) were tested using 4-factor ANOVAs. Homogeneity of variances was tested using Cochran's test and data were transformed when necessary (Underwood 1997, Winer et al. 1999). When homogeneity of variances could not be achieved by transformation, data were analysed nonetheless, since analysis of variance is robust for departure from this assumption when there are many independent replicates and sizes of samples are equal (Underwood 1997). Interaction terms were pooled when appropriate and SNK tests were used for a posteriori comparisons of the means.

\section{RESULTS}

\section{Multivariate analyses}

In general, at each stage of succession, a similar suite of taxa colonised the clearings on seawalls and rocky shores. However, assemblages developing in clearings differed between structures at each time of sampling and at each location (Fig. 2, Table 1). This pattern suggests that differences between structures were due to variation in relative abundances and in frequencies of occurrence of species, rather than in species composition. Clearings were rapidly colonised by a biofilm (a thick matrix including diatoms, unidentifiable juvenile algal stages and, probably, bacteria) and by a variety of algae, including the brown fleshy alga Endarachne binghamiae, the brown encrusting alga Ralfsia verrucosa, Ulvales and, to a lesser extent, the green filamentous alga Rhizoclonium implexum, blue-greens and other filamentous forms (mainly Chaetomorpha sp. 
and Enteromorpha spp.). Other taxa, including the red encrusting alga Hildenbrandia rubra, the tubeworm Galeolaria caespitosa, the barnacles Tesseropora rosea, Elminius covertus, Hexaminius sp., Chthamalus antennatus and Tetraclitella purpurascens and the oyster Saccostrea commercialis only colonised the clearings at later stages of succession. Across the 3 locations, 32, 51 and 42 taxa were found at Times 1, 2
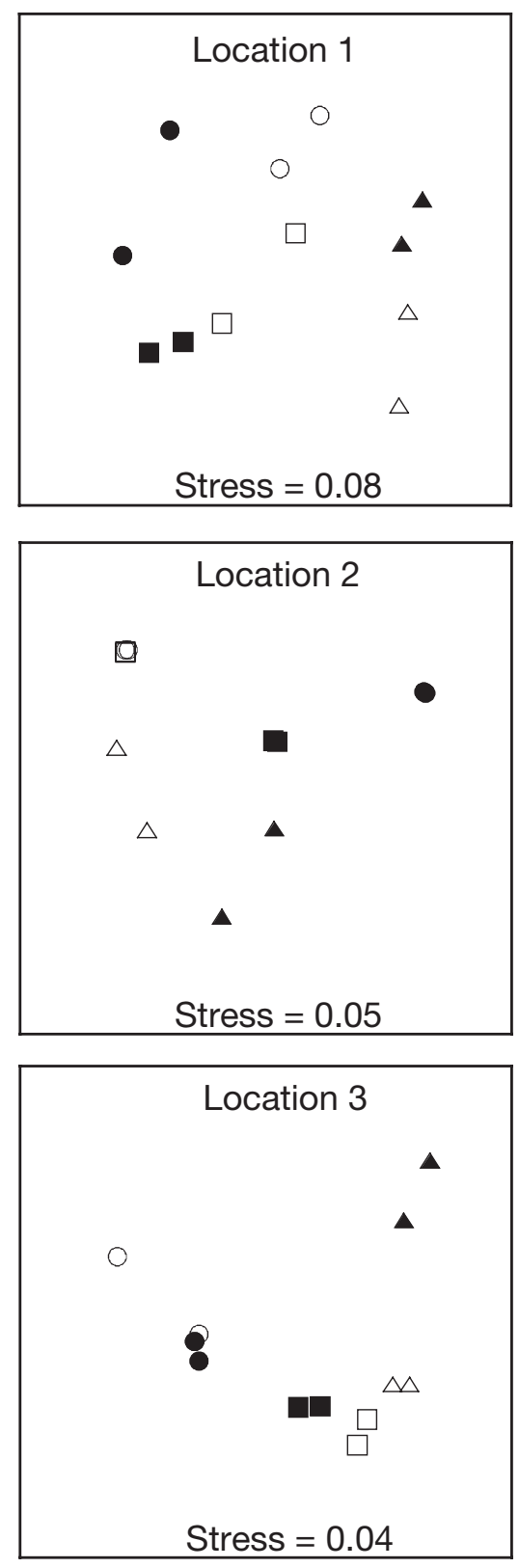

Fig. 2. Two-dimensional nMDS ordination on untransformed data, comparing assemblages in clearings between rocky shores (filled) and seawalls (open) at different times from the start of the experiment (Time 1: O; Time 2: $\boldsymbol{\square} \square$; Time 3: $\boldsymbol{\Delta} \Delta$ ), separately for each location. Each point is the centroid from 1 patch and 3, respectively. However, few taxa (2 or 3 ) made a major contribution to differences between assemblages in clearings on seawalls and rocky shores at each combination of location and time (Table 2).

At Location 1, bare rock (which is a measure of the amount of space left unoccupied) and Ralfsia verrucosa distinguished between structures at Times 1 and 2 . Other taxa contributed to differences between structures only at certain stages of the colonisation: Endarachne binghamiae at Time 1, Rhizoclonium implexum at Time 2 and Galeolaria caespitosa and Saccostrea commercialis at Time 3.

At Location 2, bare rock distinguished between structures at all times. Ulvales were important differentiators at Time 1, Ralfsia verrucosa was important at Time 2, while Hildenbrandia rubra and Saccostrea commercialis were important at Time 3.

At Location 3, Ralfsia verrucosa was the only species which distinguished between structures consistently through time. Ulvales also contributed to differences between structures at Times 1 and 2, while Endarachne binghamiae and Hildenbrandia rubra were important differentiators at Times 1 and 3, respectively.

The dissimilarity between clearings and controls between structures was significantly larger than that between clearings and controls within a structure at Times 2 and 3 at Location 2, and at Time 3 at Location 3 (Fig. 3b,c and SNK tests; analysis on untransformed data; $C=0.18, \mathrm{p}<0.05$; Time $\times$ Location $\times$ Within versus Between: $\mathrm{MS}=1064.42, F_{4,108}=4.09, \mathrm{p}<0.01$ ), indicating a tendency for assemblages in clearings to become more similar to mature assemblages on the same kind of structure. In contrast, there were no differences between dissimilarity measures at Location 1 (Fig. 3a and SNK tests).

In addition, the interaction Location $\times$ Structure $\times$ Within versus Between was significant (MS $=1015.32$, $\left.F_{2,108}=3.90, \mathrm{p}<0.05\right)$ and the SNK tests showed that the dissimilarity between clearings on the seawall and controls on the rocky shore was larger than that between clearings and controls on the seawall at Locations 2 and 3.

\section{Univariate analysis}

Few taxa which make up the major components of mature assemblages on rocky shores and seawalls (Bulleri et al. in press) colonised the clearings within 6 mo of the beginning of this study (Fig. 4). Most, including Hildenbrandia rubra, barnacles (Tesseropora rosea, Elminius covertus, Hexaminius sp., Chthamalus antennatus and Tetraclitella purpurascens were not very abundant and so were pooled into a single category for analysis), Galeolaria caespitosa and SaC- 
Table 1. NP-MANOVAs on untransformed data, comparing assemblages between clearings on rocky shores and seawalls at different times, separately for each location. Values of average dissimilarity within and between structures are reported for a posteriori comparisons. ${ }^{*} \mathrm{p}<0.05{ }^{* *} \mathrm{p}<0.01 ;{ }^{* * *} \mathrm{p}<0.001$

\begin{tabular}{|c|c|c|c|c|c|c|c|}
\hline \multicolumn{2}{|c|}{ Source of variation } & \multicolumn{2}{|c|}{ Location 1} & \multicolumn{2}{|c|}{ Location 2} & \multicolumn{2}{|c|}{ Location 3} \\
\hline & df & MS & $F$ & MS & $F$ & MS & $F$ \\
\hline Time $(\mathrm{T})$ & 2 & 17839 & \multirow[b]{3}{*}{$3.96^{* *}$} & 21875 & \multirow[b]{3}{*}{$12.45^{* * *}$} & 27930 & \multirow[b]{3}{*}{$8.90^{* *}$} \\
\hline Structure (S) & 1 & 14511 & & 31555 & & 10443 & \\
\hline $\mathrm{T} \times \mathrm{S}$ & 2 & 5852 & & 9152 & & 9094 & \\
\hline Residual & 42 & 1476 & & 734 & & 1021 & \\
\hline \multicolumn{8}{|c|}{ A posteriori comparisons } \\
\hline Location & Comparison & $\begin{array}{l}\text { Time } 1 \\
\text { Dissimilarity }\end{array}$ & $1-\frac{}{p}$ & $\begin{array}{l}\text { Time } 2 \\
\text { Dissimilarity }\end{array}$ & $\bar{p}$ & $\begin{array}{l}\text { Time } 3 \\
\text { Dissimilarity }\end{array}$ & $3-$ \\
\hline \multirow[t]{3}{*}{1} & Within SW & \multicolumn{2}{|l|}{43.57} & \multicolumn{2}{|l|}{60.11} & \multicolumn{2}{|l|}{56.30} \\
\hline & Within RS & \multicolumn{2}{|l|}{56.71} & \multicolumn{2}{|l|}{32.97} & 52.40 & \multirow{2}{*}{$* *$} \\
\hline & Between SW and RS & 73.89 & $* * *$ & 62.11 & ${ }^{* *}$ & 62.57 & \\
\hline \multirow[t]{3}{*}{2} & Within SW & 1.27 & & \multicolumn{2}{|l|}{26.32} & \multicolumn{2}{|l|}{40.71} \\
\hline & Within RS & 37.17 & & \multicolumn{2}{|l|}{29.31} & 43.66 & \multirow{2}{*}{ * } \\
\hline & Between SW and RS & 88.01 & $* * *$ & 74.34 & $* * *$ & 49.01 & \\
\hline \multirow[t]{3}{*}{3} & Within SW & 50.60 & & \multicolumn{2}{|l|}{34.95} & \multicolumn{2}{|l|}{18.50} \\
\hline & Within RS & 59.28 & & 37.84 & & 52.60 & \\
\hline & Between SW and RS & 66.57 & * & 42.12 & * & 79.82 & $* * *$ \\
\hline
\end{tabular}

costrea commercialis, colonised the clearings relatively late and, in some cases, showed different patterns between structures (Fig. 4). For instance, at Time 3, the cover of $H$. rubra (Fig. 4a) was significantly

Table 2. Variables that contributed more than $10 \%$ at least once (in bold) to measures of dissimilarity between clearings on rocky shores and seawalls. Their percentage contribution to dissimilarity is reported separately for each combination of location and time

\begin{tabular}{|lccr|}
\hline Variable & Time 1 & $\begin{array}{c}\text { Time } 2 \\
\text { Location } 1\end{array}$ & Time 3 \\
\hline Bare rock & & $\mathbf{2 1 . 5}$ & \\
Endarachne binghamiae & $\mathbf{2 2 . 0}$ & 0.0 & 6.1 \\
Galeolaria caespitosa & $\mathbf{1 4 . 5}$ & 1.3 & 0.0 \\
Ralfsia verrucosa & 0.10 & $\mathbf{3 2 . 8}$ & $\mathbf{1 0 . 8}$ \\
Rhizoclonium implexum & $\mathbf{2 1 . 8}$ & $\mathbf{1 1 . 2}$ & 0.2 \\
Saccostrea commercialis & 5.4 & 0.0 & 0.0 \\
& 0.0 & Location 2 & \\
& & $\mathbf{1 6 . 4}$ \\
Bare rock & $\mathbf{3 8 . 0}$ & $\mathbf{2 9 . 1}$ \\
Hildenbrandia rubra & $\mathbf{3 0 . 6}$ & 0.0 & $\mathbf{1 0 . 2}$ \\
Saccostrea commercialis & 0.0 & $\mathbf{2 8 . 5}$ \\
Ralfsia verrucosa & 0.0 & 0.2 & 6.4 \\
Ulvales & 4.3 & $\mathbf{4 1 . 4}$ & 0.0 \\
& $\mathbf{3 6 . 5}$ & & \\
\hline Endarachne binghamiae & $\mathbf{2 5 . 7}$ & 2.2 & 0.1 \\
Hildenbrandia rubra & 0.0 & 0.0 & $\mathbf{1 5 . 8}$ \\
Ralfsia verrucosa & $\mathbf{1 2 . 1}$ & $\mathbf{1 8 . 2}$ & $\mathbf{2 7 . 8}$ \\
Ulvales & $\mathbf{2 2 . 6}$ & $\mathbf{3 4 . 9}$ & 0.0 \\
\hline
\end{tabular}

larger on rocky shores than on seawalls at each location, while the cover of barnacles (Fig. 4b) only at Locations 2 and 3 (Table 3 and SNK tests). In contrast, at Time 3, although the analysis did not show significant differences between structures (Table 3), the cover of G. caespitosa tended to be larger on seawalls than on rocky shores (Fig. 4c). Oysters were important components of assemblages by the end of the experiment, but their cover was only significantly larger on the rocky shore than on the seawall at Location 3 (Fig. 4d, Table 3 and SNK tests).

The abundances of those taxa which distinguished between structures at earlier stages of succession were also analysed, including the amount of bare rock, which was significantly larger on seawalls at Times 1 and 2, but not at Time 3 (Fig. 5a, Table 3 and SNK tests).

The percentage cover of Ralfsia verrucosa was significantly larger on the rocky shore than on the seawall at Locations 1 and 2 at Time 2, while the opposite pattern was evident at Location 3 at Time 3 (Fig. 5b, Table 3 and SNK tests). Ulvales were significantly more abundant on the rocky shore than on the seawall at Location 2 at Time 1 

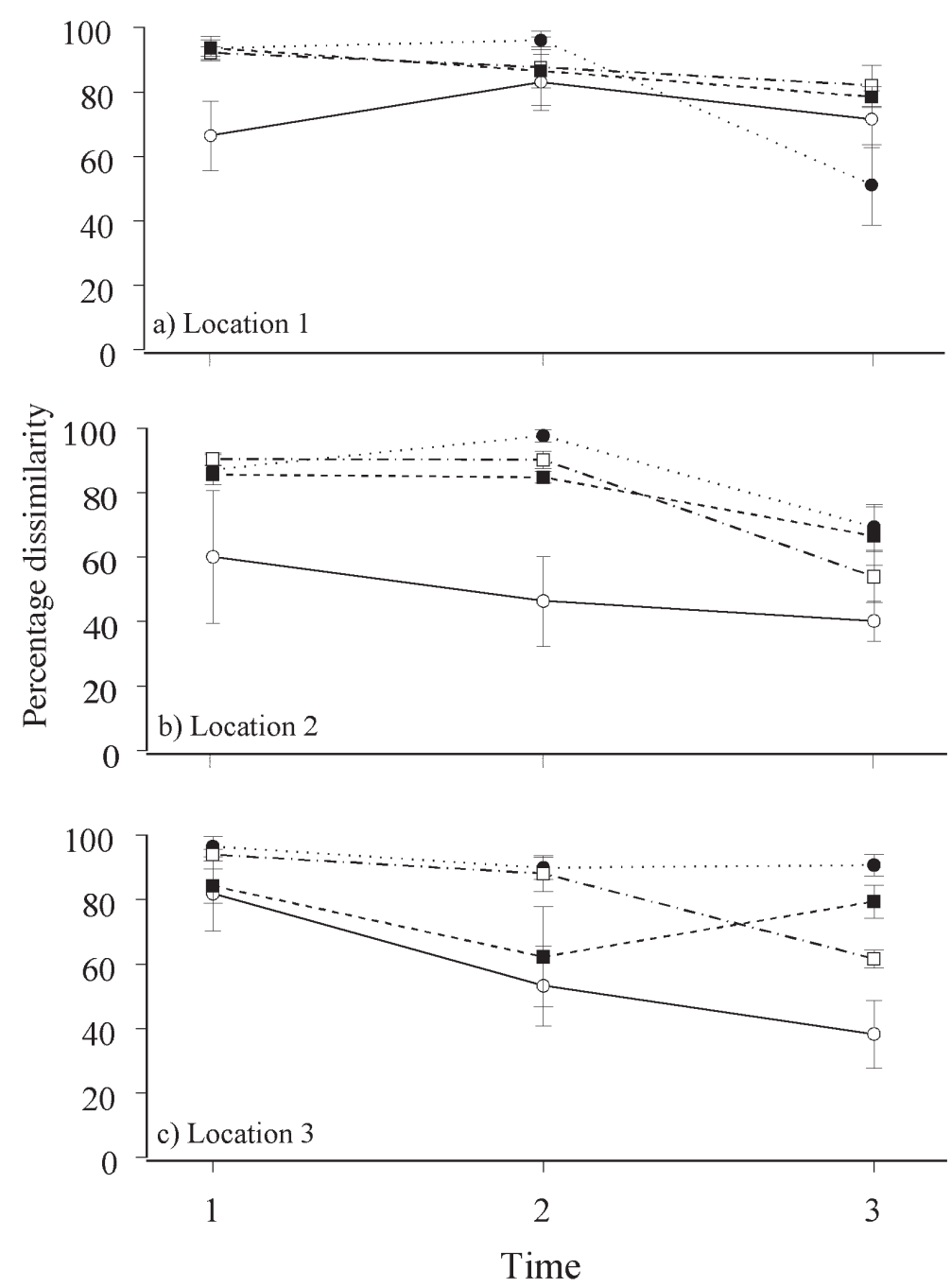

Fig. 3. Mean dissimilarity $( \pm \mathrm{SE})$ between clearings and controls within the seawall $(\mathrm{O})$, between clearings on the seawall and controls on the rocky shore $(\bullet)$, between clearings and controls within the rocky shore $(\square)$, and between clearings on the rocky shore and controls on the seawall (घ) at different times from the start of the experiment (Time 1: $3 \mathrm{mo}$; Time 2: $6 \mathrm{mo}$; Time 3: $24 \mathrm{mo})$ separately for each location $(\mathrm{n}=4)$

and at Location 3 at Times 1 and 2 (Fig. 5c, Table 3 and SNK tests). Finally, the percentage cover of Endarachne binghamiae (Fig. 5d, Table 3) did not differ significantly between structures, although at Locations 1 and 2, this alga only colonised clearings on the rocky shores at Time 1 (SNK tests).

\section{DISCUSSION}

Assemblages on rocky shores and seawalls differed from early stages of succession and differences persisted through time. These results support the model that intrinsic features of the natural and artificial struc- tures investigated here affect recruitment of organisms (sensu Connell 1985), causing different assemblages to develop on rocky shores or seawalls.

Two months after the experiment started, differences between structures were mostly due to the large amount of uncolonised space (bare rock) on seawalls, in particular at Locations 1 and 2. This may have been caused either by limited supply or slower settlement of larvae and propagules or, alternatively, by greater early mortality of newly settled individuals on seawalls. Given that most of the taxa observed during the early phases of the succession were common, although not dominant, in surrounding assemblages on rocky shores and seawalls, a different supply of algal propagules and spores (recruits of invertebrates were nearly absent at this early stages) was unlikely (Menge et al. 1993, Chapman \& Underwood 1998). Different topographic features of these structures, through influencing local hydrodynamic conditions, could be responsible for differences in recruitment between seawalls and rocky shores. As suggested by several authors (Santelices 1990, Abelson \& Denny 1997, Taylor \& Schiel 2003), hydrodynamic conditions, in terms of flow and turbulence, can be important in determining fertilisation success and/or the scales at which settlers can contact the substratum.

Alternatively, faster mortality soon after settlement on seawalls than on rocky shores could have produced the observed patterns. Assuming that the supply of competent settlers was equal between rocky shores and seawalls and that comparable numbers of propagules settled on the 2 kinds of surfaces, mortality due to physical and/or biotic factors may have been more effective at reducing the overall rates of recruitment on seawalls than on rocky shores. Vadas et al. (1992) reported that mortality of early post-settlement stages of algae was affected by a complex interplay of biotic factors, including grazing by herbivores, intra- and inter-specific competition and physical factors, such as topography of the substratum and water motion. In this experiment, slow-moving grazers were excluded from the clearings, but other relatively fast-moving herbivores, such as crabs, were left untouched. Grapsid crabs, belonging to the genera Plagusia and Leptograpsus, can be common in intertidal rocky habitats in Sydney Harbour. Robles (1982) showed that Pachygrapsus cras- 
Location 1

a) Hildenbrandia rubra

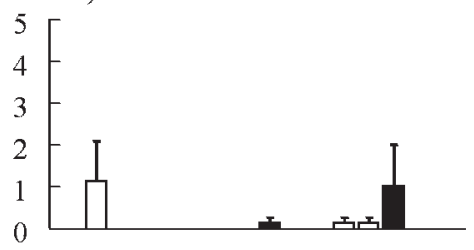

b) Barnacles

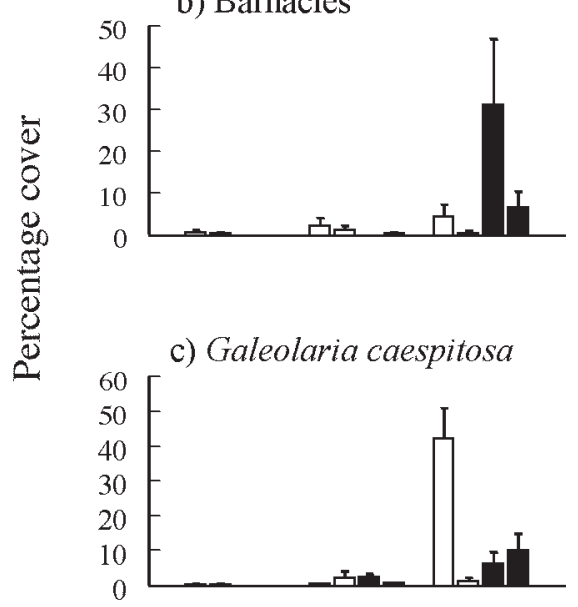

d) Saccostrea commercialis

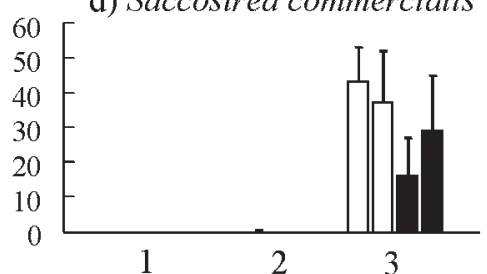

Location 2
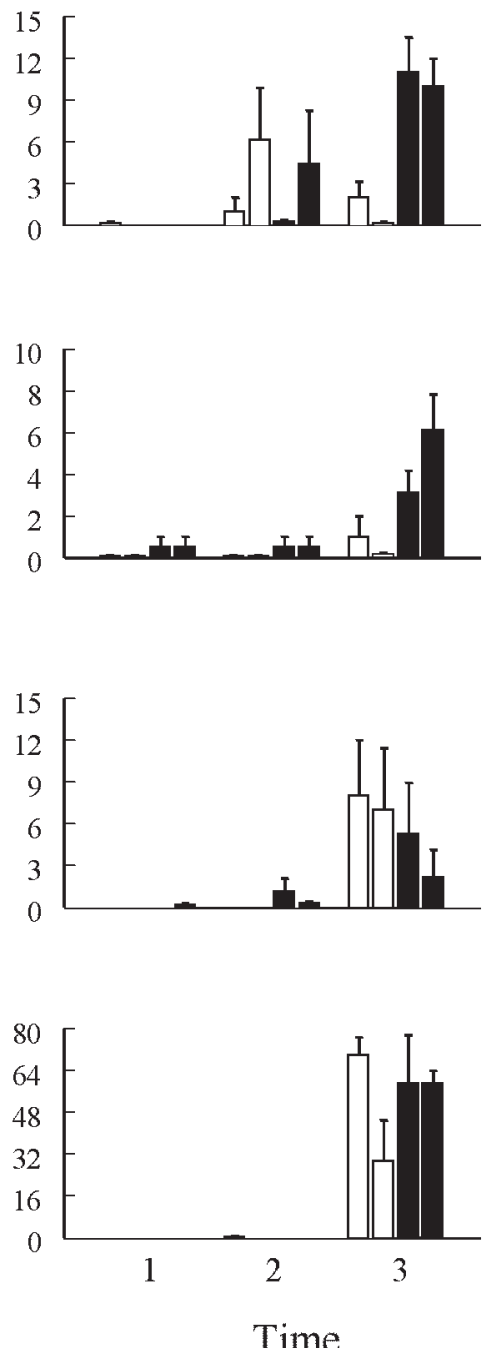

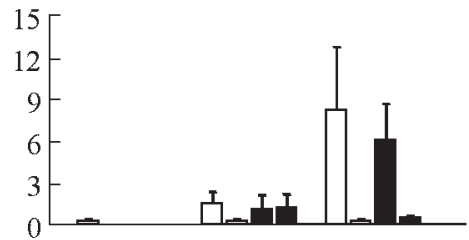

Location 3
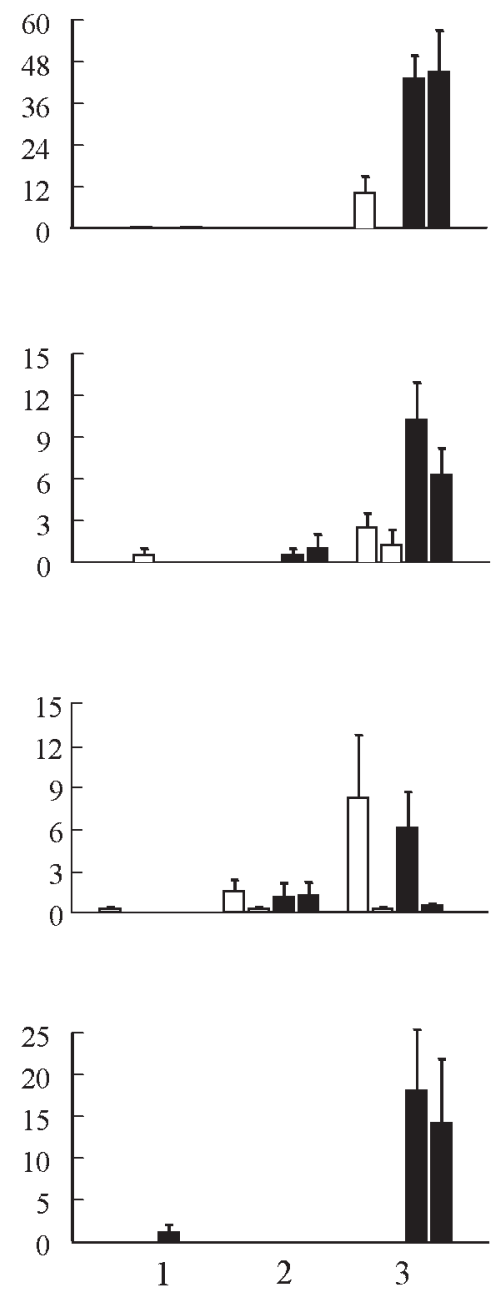

Fig. 4. Mean percentage cover (+SE) of later colonisers in clearings on seawalls (open bars) and rocky shores (filled bars) at each combination of location and time (Time 1: $3 \mathrm{mo}$; Time 2: $6 \mathrm{mo}$; Time 3: $24 \mathrm{mo}$ ). Data are values from 4 replicate clearings for each patch of habitat. Note the different $y$-axis scales

sipes was attracted by blooms of ephemeral algae colonising experimental plates and readily grazed them down to a thin film. Although crabs were not observed in large numbers during visits to the field at low tide, the large availability of crevices might have enhanced their abundance on seawalls (F. Bulleri pers. obs.).

Location-specific differences between natural and artificial habitats can be complex, due to differing topographical features, hydrodynamic regimes and life-history traits of dominant species. For example, after $6 \mathrm{mo}$, there was a marked increase in the cover of Ralfsia verrucosa; this was greater on rocky shores than on seawalls at Locations 1 and 2, while the opposite trend was found at Location 3. By $24 \mathrm{mo}$, the cover of $R$. verrucosa had strongly declined at Locations 1 and 2, whilst attaining large cover on the seawall at Location 3. Bertness et al. (1983) suggested that $R$. verrucosa may show different life-history traits in contrasting habitats. Here, the configuration of the shoreline and the degree of wave-exposure (Wolanski \& Hamner 1988, Archambault \& Bourget 1996, 1999) could have been important in determining patterns of early colonisation among locations in this study. For instance, Location 3 was a small rocky island (Clark Island, Fig. 1), approximately $300 \times 60 \mathrm{~m}$. The southeastern tip (where this study was performed) is separated from the mainland by a relatively narrow and deep channel. Ferries for public transport operating in the harbour and a variety of commercial vessels pass 


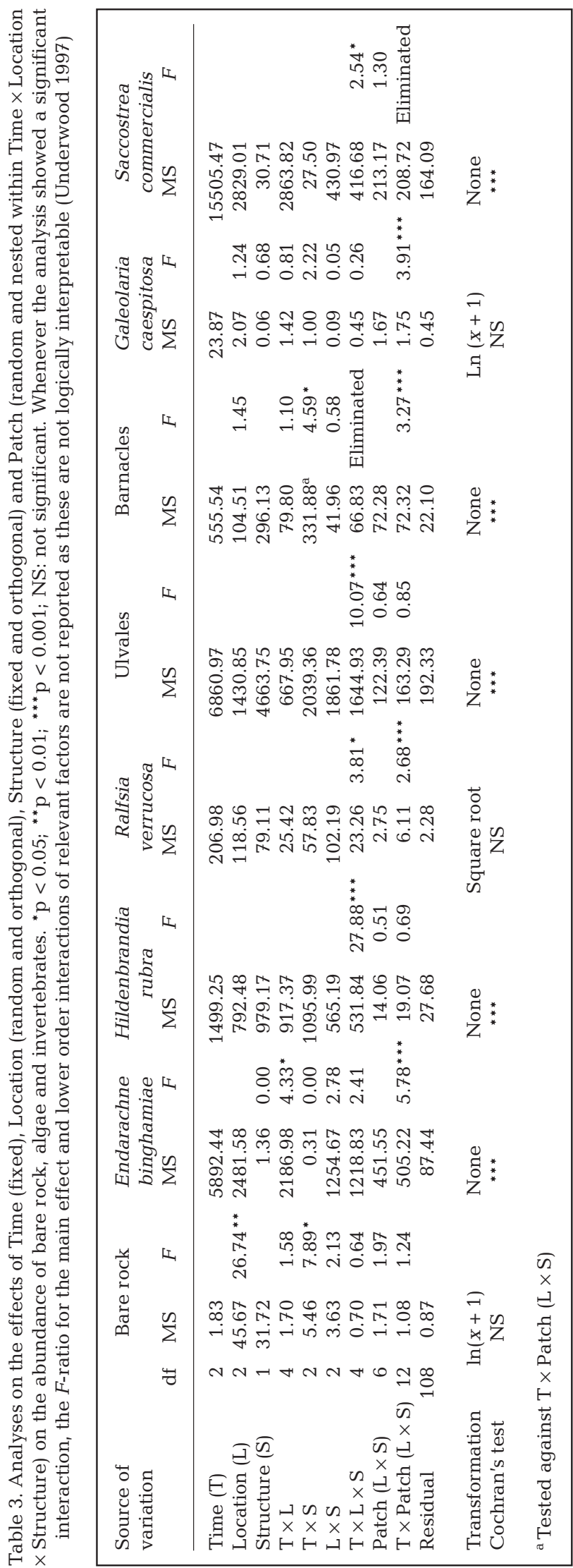

very close to the island, producing large waves that break on the foreshore after travelling a short distance in relatively deep water. Conversely, at the other locations, the subtidal part of the shore rises up more gradually, lessening the severity of wave-action. Increased moisture from intense wave-splashing may have enabled $R$. verrucosa to colonise surfaces at Clark Island (Kaehler \& Williams 1997).

The colonisation of clearings by another encrusting alga, Hildenbrandia rubra, which was previously documented to be more abundant on rocky shores than seawalls (Bulleri et al. in press), was scant during early stages of colonisation, but was greater on rocky shores by the end of the study. In contrast to Ralfsia verrucosa, $H$. rubra appears to be a slow-growing, long-lived species which recruits very slowly (Underwood 1980, Bertness et al. 1983). Kaehler \& Williams (1996) suggested that $H$. rubra is competitively subordinate to most invertebrates and algal species, and therefore its persistence could rely on the high pressure of consumers. Here, the removal of grazers, by enhancing the colonisation of $R$. verrucosa (Bertness et al. 1983, Kaeheler \& Williams 1997), may have prevented recruitment of $H$. rubra during early phases. The larger cover of $H$. rubra on rocky shores was not, however, determined by patterns of distribution of $R$. verrucosa, as the cover of this brown crust was sparse on both structures by the end of the study (except for the seawall at Location 3).

After about $2 \mathrm{yr}$ from the start of the experiment, invertebrates such as barnacles, the oyster Saccostrea commercialis and the tubeworm Galeolaria caespitosa colonised cleared areas. These species, together with Hildenbrandia rubra, are important components of mature assemblages on rocky shores and seawalls in the area (Bulleri et al. in press). Patterns of colonisation of seawalls and rocky shores by barnacles and G. caespitosa reflected distributions in mature assemblages (Bulleri et al. in press); barnacles tended to be more abundant on rocky shores, while G. caespitosa was more abundant on seawalls. Oysters colonised both types of structures at Locations 1 and 2, but only the rocky shore at Location 3. At the latter location (Clark Island), Ralfsia verrucosa might have prevented colonisation by oysters (Bertness et al. 1983, Dungan 1986). Therefore, even if this alga can only occupy space for relatively limited periods of time (Bertness et al. 1983, this study), its effects on assemblages may last long after its disappearance, having important ramifications for later development of assemblages on rocky shores and seawalls.

Some authors (Dye 1998, Jenkins et al. 2004) have reported long-lasting effects ( 7 to $13 \mathrm{yr}$ ) of disturbances on intertidal assemblages, while others have shown that they tend to move toward the initial state 


\section{Location 1}

a) Bare rock

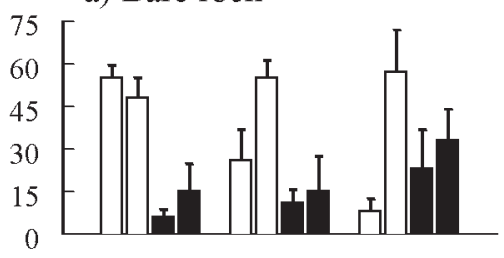

b) Ralfsia verrucosa
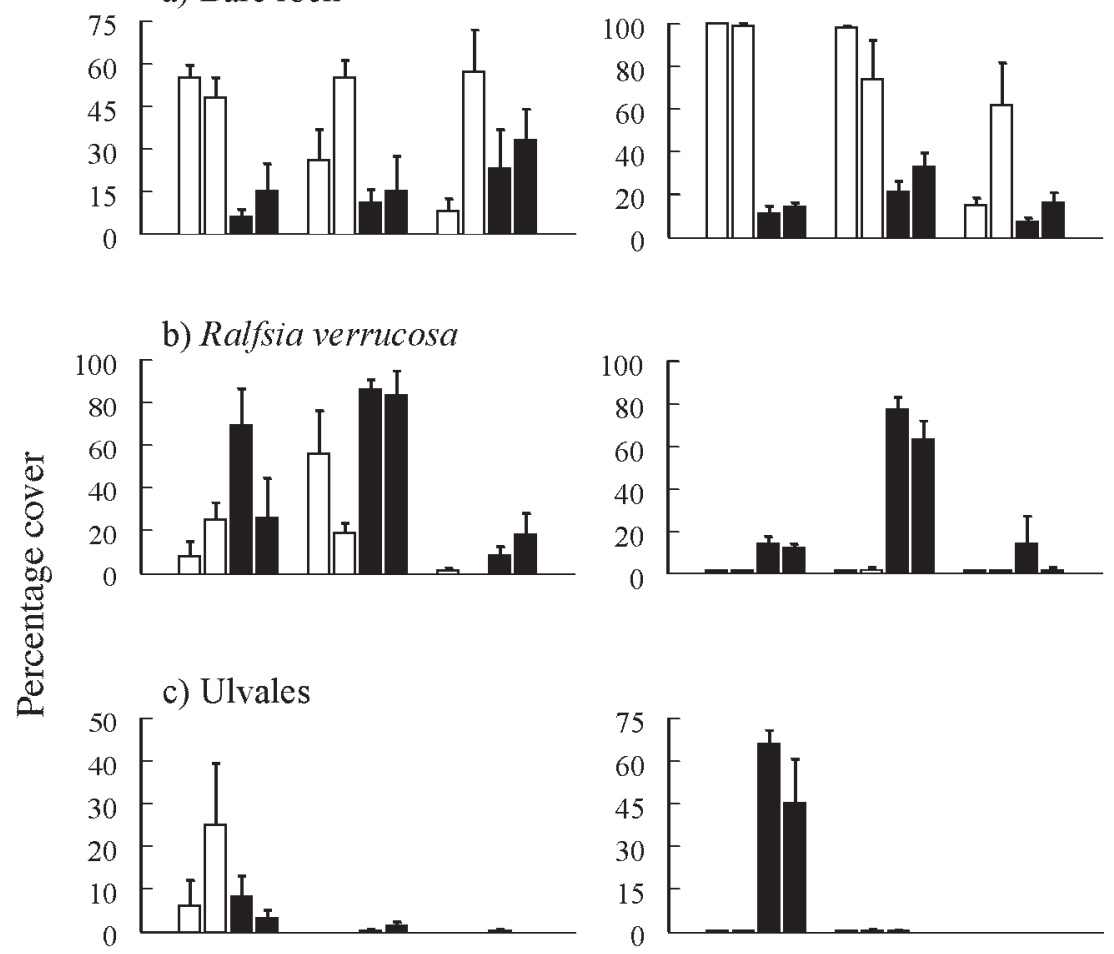

d) Endarachne binghamiae

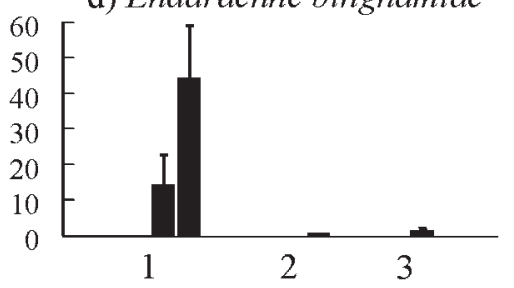

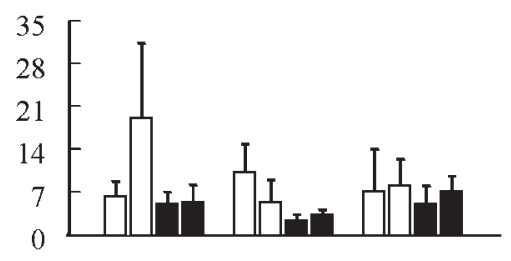

Location 3
Location 2

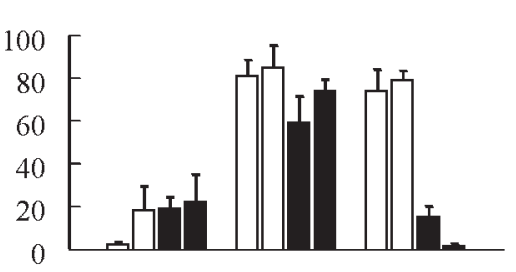

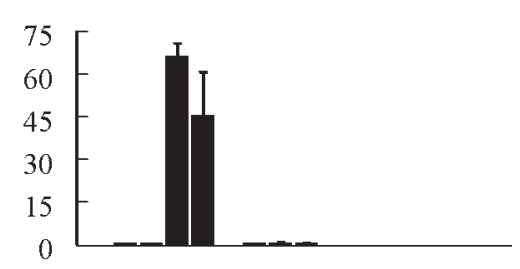
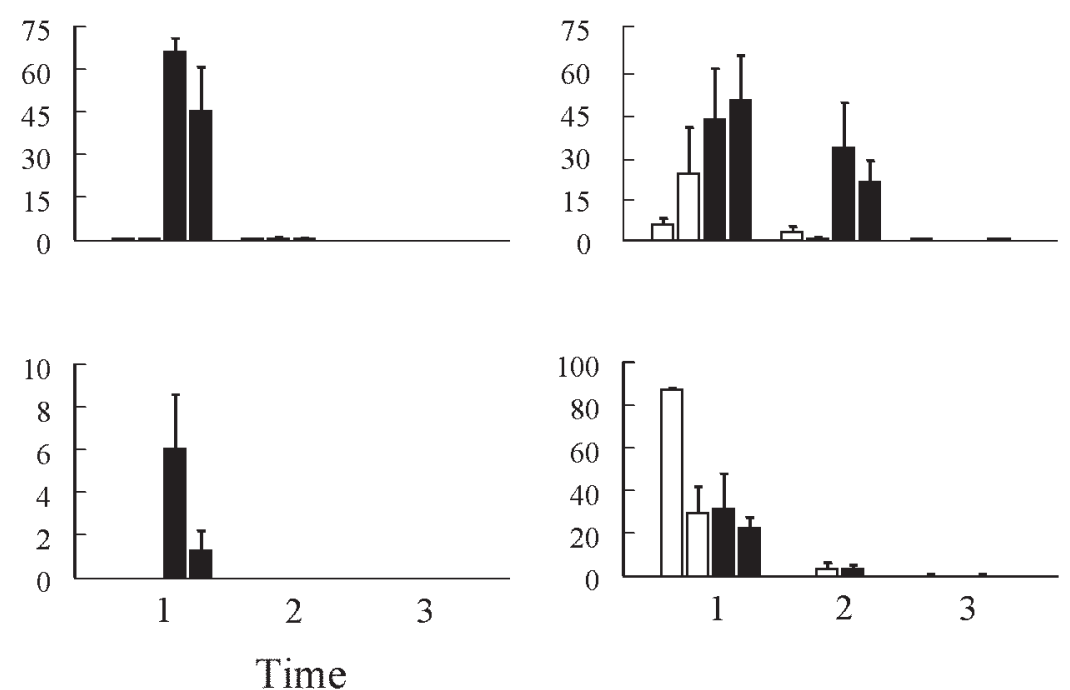

Fig. 5. Mean percentage cover (+SE) of early colonisers in clearings on seawalls (open bars) and rocky shores (filled bars) at each combination of location and time (Time 1: $3 \mathrm{mo}$; Time 2: $6 \mathrm{mo}$; Time 3: $24 \mathrm{mo}$ ). Data are values from 4 replicate clearings for each patch of habitat. Note the different $y$-axis scales

(Sousa 1980, Chapman \& Underwood 1998). At Locations 2 and 3, assemblages developing on each structure tended to converge toward surrounding mature assemblages, although this was only apparent after 24 mo. In contrast, at Location 1, despite mature assemblages differing between structures at the time this experiment was performed (Bulleri et al. in press), assemblages in clearings did not become more similar to surrounding stands of organisms, on either the rocky shore or the seawall. Once again, this may be dependent on the life-histories of the species occupying most of the space at a given location at that time (Bulleri et al. in press). In particular at Location 1, oysters, although generally more abundant on the rocky shore, were an important component of mature assemblages on both structures (Bulleri et al. in press).

The time of the initiation of experiments has been shown to be crucial in determining the structure of developing benthic assemblages (Reed et al. 1988, Underwood \& Anderson 1994, Anderson \& Underwood 1997, Chapman \& Underwood 1998). Here, seasonal and other temporal effects of recruitment on seawalls and rocky shores were not investigated because of the limited space available to repeat experiments. The patterns of recruitment could, therefore, have been, in part, a consequence of the time when the study was 
started. On the other hand, the recruitment of species into cleared areas was generally slow, in particular on seawalls, so that bare space was available for colonisation throughout the duration of the study. This suggests that, during the course of the experiment, any temporal difference in recruitment would have been seen.

In conclusion, there is evidence for colonisation of available space to differ between rocky shores and seawalls from early stages, suggesting that variation in recruitment of algae and invertebrates between natural and artificial structures can be important in determining the occurrence of distinct mature assemblages. Future studies, replicated at appropriate scales, should attempt to identify the specific factors causing recruitment of organisms to vary between these natural and artificial structures.

As a consequence of global climate changes, such as a rise in the sea level (Cabanes et al. 2001) and frequency of storms (Carter \& Draper 1988, Grevemeyer et al. 2000), a further increase in artificial retaining structures (e.g. seawalls, breakwaters) can be predicted in the next few decades. As artificial structures are inevitably going to be introduced in shallow coastal waters, being able to minimise changes caused to natural assemblages of organisms should be a priority (Peters 1991). Only through an understanding of the mechanisms which cause assemblages on artificial structures to differ from those occurring on natural habitats, can the design of artificial structures be improved. Despite the visual impact, the severity of fragmentation or loss of natural habitats caused by the introduction of artificial structures in shallow waters could be considerably reduced in the case in which they would maintain natural patterns of distribution and abundance of organisms, scales of variability and relevant ecological processes.

Acknowledgements. I wish to thank G. Chapman and T. Underwood for their help and guidance throughout all the stages of this study. G. Chapman, B. Kelaher, L. Benedetti-Cecchi, F. Bacchiocchi and 2 anonymous referees offered highly valuable comments on early drafts of the manuscript. This study was supported by an International Postgraduate Scholarship from the University of Sydney and funds from the Australian Research Council through its Special Centres Programme. M. Abbiati provided facilities at the Centro Interdipartimentale per la Ricerca nelle Scienze Ambientali in Ravenna (Università di Bologna), during the preparation of the final version of the manuscript, while F.B. was supported by funds from EU project EVK3-CT-2000-00041 (DELOS) and from COFIN 2002 (ex $40 \%$ ).

\section{LITERATURE CITED}

Abelson A, Denny M (1997) Settlement of marine organisms in flow. Annu Rev Ecol Syst 28:317-339

Anderson MJ (2001) A new method for non-parametric multi- variate analysis of variance. Aust Ecol 26:32-46

Anderson MJ, Underwood AJ (1994) Effects of substratum on the recruitment and development of an intertidal estuarine fouling assemblage. J Exp Mar Biol Ecol 184:217-236.

Anderson MJ, Underwood AJ (1997) Effects of gastropod grazers on recruitment and succession of an estuarine assemblage: a multivariate and univariate approach. Oecologia 109:442-453

Archambault P, Bourget E (1996) Scales of coastal heterogeneity and benthic intertidal species richness, diversity and abundance. Mar Ecol Prog Ser 136:111-121

Archambault P, Bourget E (1999) Influence of shoreline configuration on spatial variation of meroplanktonic larvae, recruitment and diversity of benthic subtidal communities. J Exp Mar Biol Ecol 238:161-184

Bacchiocchi F, Airoldi L (2003) Distribution and dynamics of epibiota on hard structures for coastal protection. Estuar Coast Shelf Sci 56:1157-1166

Benedetti-Cecchi L (2000) Predicting direct and indirect interactions during succession in a mid-littoral rocky shore assemblage. Ecol Monogr 70:45-72

Bertness MD, Yund PO, Brown AF (1983) Snail grazing and the abundance of algal crusts on a sheletered New England rocky beach. J Exp Mar Biol Ecol 71:147-164

Bourget E, DeGuise J, Daingle G (1994) Scales of substratum heterogeneity, structural complexity, and the early establishment of a marine epibenthic community. J Exp Mar Biol Ecol 181:31-51

Bray JR, Curtis JT (1957) An ordination of the upland forest communities of southern Wisconsin. Ecol Monogr 27:325-349

Bulleri F, Chapman MG (2004) Intertidal assemblages on artificial and natural habitats in marinas on the north-west coast of Italy. Mar Biol 145:381-391

Bulleri F, Menconi M, Cinelli F, Benedetti-Cecchi L (2000) Grazing by two species of limpets on artificial reefs in the northwest Mediterranean. J Exp Mar Biol Ecol 255:1-19

Bulleri F, Chapman MG, Underwood AJ (in press) Intertidal assemblages on seawalls and vertical rocky shores in Sydney Harbour (Australia). Aust Ecol

Cabanes C, Cazenave A, Le Provost C (2001) Sea level rising during past 40 years determined from satellite and in situ observations. Science 294:840-842

Caffey HM (1985) Spatial and temporal variation in the settlement and recruitment of intertidal barnacles. Ecol Monogr 55:313-335

Carter DJT, Draper L (1988) Has the north-east Atlantic become rougher? Nature 332:94

Chapman MG (2003) Paucity of mobile species on constructed seawalls: effects of urbanization on biodiversity. Mar Ecol Prog Ser 264:21-29

Chapman MG, Bulleri F (2003) Intertidal seawalls - new features of landscape in intertidal environments. Landsc Urban Plan 62:159-172

Chapman MG, Underwood AJ (1998) Inconsistency and variation in the development of rocky intertidal algal assemblages. J Exp Mar Biol Ecol 224:265-289

Clarke KR (1993) Non-parametric multivariate analyses of changes in community structure. Aust Ecol 18:117-143

Clements FE (1936) Nature and the structure of the climax. J Ecol 24:252-284

Connell JH (1985) The consequences of variation in initial settlement vs. post-settlement mortality in rocky intertidal communities. J Exp Mar Biol 93:11-45

Connell JH, Slatyer RO (1977) Mechanisms of succession in natural communities and their role in community stability and organization. Am Nat 111:1119-1144

Connell JH, Noble IR, Slatyer RO (1987) On the mechanisms 
producing successional change. Oikos 50:136-137

Connell SD, Glasby TM (1999) Do urban structures influence local abundances and diversity of subtidal epibiota? A case study from Sydney Harbour, Australia. Mar Environ Res 47:1-15

Crawford DW, Bonnevie NL, Wenning RJ (1995) Sources of pollution and sediment contamination in Newark Bay, New Jersey. Ecotoxicol Environ Saf 30:85-100

Davis JLD, Levin LA, Walther SM (2002) Artificial armored shorelines: sites for open-coast species in a southern California Bay. Mar Biol 140:1249-1262

Dayton PK (1971) Competition, disturbance and community organization: the provision and subsequent utilization of space in a rocky intertidal community. Ecol Monogr 41:351-389

Denley EJ, Underwood AJ (1979) Experiments on factors influencing settlement, survival and growth of two species of barnacles in New South Wales. J Exp Mar Biol Ecol 36: 269-293

Denny MW (1988) Biology and the mechanics of wave-swept environments. Princeton University Press, Princeton

Dungan ML (1986) Three-way interactions: barnacles, limpets, and algae in a Sonoran desert rocky intertidal shore. Am Nat 127:292-316

Dye AH (1998) Community-level analyses of long-term changes in rocky littoral fauna from South Africa. Mar Ecol Prog Ser 164:47-57

Gabric AJ, Bell PRF (1993) Review of the effects of non point nutrient loading on coastal ecosystems. Aust J Mar Freshw Res 44:261-283

Gilbert OL (1989) The ecology of urban habitats. Chapman \& Hall, London

Glasby TM (1999) Differences between subtidal epibiota on pier pilings and rocky reefs at marinas in Sydney, Australia. Estuar Coast Shelf Sci 48:281-290

Glasby TM, Connell SD (1998) Urban structures as marine habitats. Ambio 28:595-598

Gray JS (1997) Marine biodivesity: patterns, threats and conservation needs. Biodivers Conserv 6:153-175

Grevemeyer I, Herber R, Essen HH (2000) Microseismological evidence for a changing wave climate in the northeast Atlantic Ocean. Nature 408:349-352

Hammond A (1992) World resources 1992-1993: towards sustainable development. Oxford University Press, Oxford

Hobbs ER (1988) Species richness in urban forest patches and implications for urban landscape diversity. Landsc Ecol 1: 141-152

Hollis JM (1991) The classification of soils in urban areas. In: Bullock P, Gregory PJ (eds) Soils in the urban environment. Blackwell Scientific Publications, Oxford, p 5-27

Holloway MG, Connell SD (2002) Why do floating structures create novel habitats for subtidal epibiota? Mar Ecol Prog Ser 235:43-52

Jenkins SR, Norton TA, Hawkins SJ (2004) Long term effects of Ascophyllum nodosum canopy removal on mid shore community structure. J Mar Biol Assoc UK 84:327-329

Kaehler S, Williams GA (1996) Distribution of algae on tropical rocky shores: spatial and temporal patterns of noncoralline encrusting algae in Hong Kong. Mar Biol 125: 177-187

Kaehler S, Williams GA (1997) Do factors influencing recruitment ultimately determine the distribution and abundance of encrusting algae on seasonal tropical shores? Mar Ecol Prog Ser 156:87-96

Lubchenco J, Menge BA (1978) Community development and persistence in a low rocky intertidal zone. Ecol Monogr 48: $67-94$

Editorial responsibility: Roger Hughes (Contributing Editor), Bangor, UK
McDonnell MJ, Pickett STA (1990) Ecosystem structure and function along urban-rural gradients: an unexploited opportunity for ecology. Ecology 71:1232-1237

McDonnell MJ, Pickett STA, Pouyat RV (1993) The application of the ecological gradient paradigm to the study of urban effects. In: McDonnell MJ, Pickett STA (eds) Humans as components of ecosystems: the ecology of subtle human effects and populated areas. Springer Verlag, New York, p 175-189

Menge BA, Farrell TM, Olson AM, van Tamelen P, Turner T (1993). Algal recruitment and the maintenance of a plant mosaic in the low intertidal region of the Oregon coast. J Exp Mar Biol Ecol 170:91-116

Paul MJ, Meyer JL (2001) Streams in the urban landscape. Annu Rev Ecol Syst 32:333-365

Peters RH (1991) A critique for ecology. Cambridge University Press, Cambridge

Pickett STA, Cadenasso ML, Grove JM, Nilon CH, Pouyat RV, Zipperer WC, Costanza R (2001) Urban ecological systems: linking terrestrial ecological, physical and socioeconomic components of metropolitan areas. Annu Rev Ecol Syst 32:127-157

Reed DC, Laur DR, Ebeling AW (1988) Variation in algal dispersal and recruitment: the importance of episodic events. Ecol Mongr 58:321-335

Robles C (1982) Disturbance and predation in an assemblage of herbivorous diptera and algae on rocky shores. Oecologia 54:23-31

Santelices B (1990) Patterns of reproduction; dispersal and recruitment in seaweeds. Oceanogr Mar Biol Annu Rev 28:177-276

Sousa WP (1979) Experimental investigations of disturbance and ecological succession in a rocky intertidal community. Ecol Monogr 49:227-254

Sousa WP (1980) The responses of a community to disturbance: the importance of successional age and species' life histories. Oecologia 45:72-81

Sousa WP (1984) Intertidal mosaics: patch size, propagule availability, and spatially variable patterns of succession. Ecology 65:1918-1935

Taylor DI, Schiel DR (2003) Wave-related mortality in zygotes of habitat-forming algae from different exposures in southern New Zealand: the importance of 'stickability'. J Exp Mar Biol Ecol 290:229-245

Underwood AJ (1980) The effects of grazing by gastropods and physical factors on the upper limits of distribution of intertidal macroalgae. Oecologia 46:201-213

Underwood AJ (1997) Experiments in ecology: their logical design and interpretation using analysis of variance. Cambridge University Press, Cambridge

Underwood AJ, Anderson MJ (1994) Seasonal and temporal aspects of recruitment and succession in an intertidal estuarine fouling assemblage. J Mar Biol Assoc UK 74:563-584

Underwood AJ, Fairweather PG (1989) Supply-side ecology and benthic marine assemblages. Trends Ecol Evol 4:16-20

Vadas RL, Johnson S, Norton TA (1992) Recruitment and mortality of early post-settlement stages of benthic algae. Br Phycol J 27:331-351

Winer BJ, Brown DR, Michels KM (1991) Statistical principles in experimental design. McGraw-Hill, New York

Wolanski E, Hamner WM (1988) Topographically controlled fronts in the ocean and their biological influence. Science 241:177-181

Zipperer WC, Foresman TW, Sisinni SM, Pouyat RV (1997) Urban tree cover: an ecological perspective. Urban Ecosyst 1:229-247

Submitted: May 30, 2004; Accepted: August 4, 2004

Proofs received from author(s): January 12, 2005 